\title{
Identifying factors influencing on the cash flow of construction companies: Evidence from Vi- etnam stock exchange
}

\author{
Thi Tu Oanh Le ${ }^{a}$, Thi Thanh Thuy $V u^{b}$ and Van Cong Nguyen ${ }^{*}$
}

\begin{tabular}{l}
${ }^{a}$ Accounting Department, University of Labour and Social Affairs (ULSA), Vietnam \\
${ }^{b}$ Accounting Department, University of Labour and Social Affairs (ULSA), Vietnam \\
cSchool of Accounting and Auditing, The National Economics University, Vietnam \\
\hline
\end{tabular}

\section{H R O N I C L E}

\section{Article history:}

Received: June 92019

Received in revised format: July 9

2019

Accepted: July 24, 2019

Available online:

July 26, 2019

Keywords:

Cash flow

Construction companies

Identifying factors

Vietnam stock exchange

\section{A B S T R A C T}

Good management of cash flow will help managers control cost estimates, control plan implementation as well as control additional costs, ensuring project success. Therefore, identifying the factors influencing the cash flow of enterprises helps create synchronous solutions to improve the efficiency of cash flow management, contributing for improving the operational efficiency of the enterprises. This study is based on a survey to determine the factors influencing the cash flow through the questionnaires and interviews of 105 construction companies listed on the Vietnam Stock Exchange in 2018. The study conducts descriptive statistics analysis of surveyed enterprises; check the Exploratory Factor Analysis (EFA) analysis conditions to determine the groups of influencing factors on cash flow in construction companies listed on the Vietnam Stock Exchange. At the same time, this study remains to check a sample T-test with a value set to 3.0 and $5 \%$ reliability and analysis of EFA discovery factors to select components with the highest coefficients and load components. Based on the EFA analysis results, the study finds six main groups of factors affecting the cash flow of construction companies. They are: macro environment; construction period; payables and receivables; construction cost; retention; loan payment and tax. The study also shows that the effect of variables to cash flow management varied with a mean value from 0.17 to 0.518 . Based on the research results, the authors provide some recommendations to strengthen cash flow management in construction companies listed on the Vietnam Stock Exchange.

(C) 2020 by the authors; licensee Growing Science, Canada

\section{Introduction}

Construction enterprises play an important role in the economy, reflecting the sustainable development of the economy and participating in most other economic sectors. Construction enterprises face many risks due to the large value of goods. If the inventory is high, slow debt recovery will affect liquidity, thereby slowing down the ongoing activities of the enterprises. Many previous studies have shown that poor liquidity is a fundamental factor affecting the breakdown of contracts and leading to the bankruptcy of construction businesses (El-Kholy, 2014). Cash flow management is one of the governance contents dominating the survival of a business. Cash flow management is an important activity to create the liquidity of a business to monitor, to analyze and to maximize the net value earned when taking the earned money minus the amount to be spent. In order to manage cash flow effectively, it is necessary to understand the factors affecting cash flow. The research on cash flow and cash flow index has been more 
focused since the beginning of 1966 in the world. Cash flow is considered as an important predictor of the enterprises' financial situation. Cash flow not only plays an essential role in credit rating but also helps business forecasting the risk of bankruptcy. The collapse of Lehman Brothers was an alarm bell to businesses for ineffective cash flow management. The cash-flow problem can influence productivity and affect the quality of the product (Gundecha, 2018).

In Vietnam, the management of cash flow in enterprises has not really been properly concerned. Since the characteristics of the construction industry are associated with large-scale products, complex structures; long construction time; companies must spend a large amount of initial capital. Finding out the factors affecting cash flow is really necessary to help businesses improve liquidity and manage cash flow effectively. This study is carried out to identify factors influencing on the cash flow of Vietnamese construction companies to find appropriate solutions to strengthen cash flow management, ensure solvency and security of financial security and contribute to improve business efficiency. The study is experimental research on identifying and analyzing the factors impact on the cash flow in Vietnamese listed construction companies. The study also recognizes the factors affecting businesses' cash flow by regression analysis. Factors are divided into groups of factors that influence cash flow by analyzing the correlation between them.

To conduct this study, the authors conducted a sample and surveyed 105 construction companies listed on the Vietnam Stock Exchange in 2018. The survey results received 102 valid responses, accounting for $97.14 \%$ in the total issued questionnaire. We believe our sampling fully meets the comprehensive and complete aspects of the research sample to ensure that research results are reliable when they are analyzed and verified. The selection of our research sample is based on the following criteria:

First, enterprise size: Selected construction enterprises include large and medium-sized enterprises, excluding small and micro-small enterprises. This stems from the characteristics of construction business that requires a large amount of capital, long production time, slow payback period so small and microsmall businesses often do not meet the requirements. Second, type of enterprise: The research samples collected are public companies, including companies that have made public offerings; The company has shares listed on HOSE, HNX, and Upcom. These are companies that make extensive capital mobilization from the public through issuing securities (stocks, bonds) listed at securities trading centers or unlisted securities but traded through securities brokerage institutions.

Finally, business field: Enterprises operating in the construction industry are divided into three groups: Building houses of all kinds, construction of civil engineering works and specialized construction. Within each industry group, there are different types of industries. For example: Construction of civil engineering works includes: Construction of railway and road works (construction of railway works, construction of road works), construction of public works (construction electrical works, construction of water supply and drainage works, construction of telecommunications, communication, construction of other public works), construction of other civil engineering works (construction of waterworks, construction of mining projects, construction of processing, manufacturing and construction of other civil engineering works) (Prime Minister, 2018). This shows the specific nature of the construction industry, the complexity, and diversity of construction business activities affecting cash flow and cash flow management. The main objective of this study is to point out the characteristics of the construction industry that affect the cash flow in construction companies in order to (i) identify the factors affecting the cash flow of construction businesses, and (ii) determine the impact of each factor on the cash flow of construction companies listed on the Vietnamese stock exchange. To achieve the goal, the authors surveyed to answer key questions: Factors affecting the cash flow of construction companies and how to examine the effect of factors on cash flow in construction companies. 


\section{Literature review}

Financial management has drawn interest to many scholars, including personal financial management and the organization's financial management. There have been a number of studies mentioning various factors affecting cash flow, including: The organization of enterprise (Ivan, 2017); Financial risk, including loan repayments, supplier debt repayments, taxes payable (Jiang et al., 2011); Retention, including retention rate, refund time and minimum retention (Bausman, 2004; Park et al., 2005); Delayed payment, including time, payment conditions and advances (Ramachandra \& James, 2011); Complaint: Complaint has a negative impact on the cost and time of the project, the late handoffs will be high to compensate for the damage that affects the project cost due to delays (Ling \& Liu, 2005); Completion according to schedule: Completion according to schedule helps the parties predict the cash flow because the payment date is calculated according to each stage of project completion (Garner, 2012); Measure the difference (redundant and missing): The amount of excess and lack of measurement is determined as the second most influential factor affecting the contractor's cash flow (Buertey \& Adjei-Kumi, 2012); The management of cash flow under the operational management system: It is affected by environmental factors and controlling subjects (Bento \& Bento, 2006); The macroeconomic factors, including information technology, politics, and law, tax policy, inflation, interest rate (Jack, 2018). The cost of raw materials accounts for a large proportion of the total cash outflows of enterprises (Dosumu; 2015); Delaying payables (3045 days) also substantially affects the cash flow of businesses (Arditi \& Chotibhongs, 2005); The factors affecting the management of cash flow of construction enterprises include: (i) Receivables (Payment term; Conditions of payment; Advance); (ii) Amounts of retention (Rate and return time); (iii) Financial status; (iv) Payables (Repayment of loans; Repayment of materials; Employee salaries payment); (v) Bank interest rates; (vi) Volume measurement (over/under) (Issa and \& Zayed, 2007); The assessment of the factors affecting the cash flow of construction projects consists of 6 groups: financial management, subcontractors, suppliers, before construction, during construction; communication skills and other factors (Tarek \& Yaqiong, 2014). The drawback of most of these studies is only the introduction of factors that influence content-based cash flow management such as accounts receivable management, accounts payable management and dark cash levels. Optimizing, forecasting cash flow, establishing relationships with financial institutions to deal with surpluses or lack of budgets without building the optimal budget model as well as determining factors affecting cash flow are among other factors influencing cash flow. On the other hand, these studies only consider and evaluate the factors affecting cash flow by each individual factor or group of factors, while construction enterprises' cash flow is dominated by a series of factors at the same time. Moreover, in Vietnam, there is hardly any specific study devoted on the impact of factors on cash flow in the construction industry. Therefore, this study will initially solve some of the limitations in previous studies and show the relationship between factors with cash flow from which to recommend effective management solutions money flow. From the review of the above studies, in this study, we focused on determining the impact of the six major groups of factors on cash flow; in which, we also consider the impact of each component. This includes Financial risk (payment for suppliers, delayed payment for suppliers, selling price adjustment, claims, loan payment, withholding tax, bank loan Interest rate) and Retention (retained rate, time of releasing retention, the limit of retention), etc.

\section{Research Methods}

To achieve the research objectives and answer research questions, we use some quantitative research method with the help of SPSS 22 specialized software. Through descriptive statistics, we conduct a summary of the data, describing the companies surveyed in the form of data tables. Next, we examine the conditions for EFA analysis and test One sample T-test. Finally, we conduct the EFA discovery factor analysis. Thus, we have an overview of the influencing factors and the relationship between the factors affecting the cash flow in Vietnamese construction companies. Research data is collected by a design questionnaire on google form and sent via email and Facebook to Vietnamese construction enterprises. The questionnaire is divided into 3 main parts: (i) Information about businesses; (ii) Factors affecting 
cash flow and (iii) Information of respondents. The research process can be summarized in Fig. 1 as follows,

(1) Design a pilot test on Google docs

\section{DESIGN THE PILOT TEST}

(2) Send to 10 construction enterprise in order to evaluate the validity and comprehension of the questions

(3) Edit according to feedback received to complete the survey form.

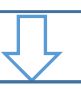

DISTRIBUTE OFFICIAL SURVEY FORMS TO ACCOUNTANTS AND BUSINESS MANAGERS

(1) Via email, Facebook and hard copy

(2) The sampling method is intentional sampling, collecting information of all construction companies listed on HOSE, HNX, and UPCOM

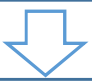

(1) The total number of the distributed questionnaire was 105

(2) The total number of responses collected is 105; in which 03 answers were removed due to inaccuracies; remaining 102 valid answers

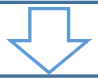

\section{ANALYZING DATA ON SPSS 22 SOFTWARE}

(1) Descriptive statistics analysis about surveyed enterprises

(2) Check the conditions of EFA analysis

(3) Testing One sample T-test with a set value of 3.0 and 5\% reliability;

(4) EFA discovery factor analysis to select the component with the highest load factor and component

Fig. 1: Conceptual framework

Source: authors' results

From the research overview, we propose a model of groups of factors influencing cash flow in Vietnamese listed construction enterprises. The scale details are shown in Table 1.

\section{Table 1}

Detailed description of the scale

\begin{tabular}{|c|c|c|}
\hline Factors & Cod & Variables \\
\hline \multirow{7}{*}{ 1. Financial risk } & F11 & Payment for suppliers \\
\hline & F12 & Delayed payment for suppliers \\
\hline & F13 & Selling price adjustment \\
\hline & F14 & Claims \\
\hline & F15 & Loan payment \\
\hline & F16 & Withholding tax \\
\hline & F17 & Bank loan Interest rate \\
\hline \multirow{3}{*}{ 2. Retention } & $\mathrm{F} 21$ & Retained rate \\
\hline & F22 & Time of releasing retention \\
\hline & F23 & Limit of retention \\
\hline \multirow{3}{*}{ 3. Receivables } & F31 & Payment duration \\
\hline & $\mathrm{F} 32$ & Terms of payment \\
\hline & F33 & Advance payment \\
\hline \multirow{3}{*}{ 4. Construction cost } & F41 & Cost of materials \\
\hline & F42 & Wages of labor and staff \\
\hline & F43 & Plan and equipment costs \\
\hline \multirow{3}{*}{ 5. During construction } & F51 & Under work measurement \\
\hline & F52 & Over work measurement \\
\hline & F53 & Work execution errors \\
\hline \multirow{6}{*}{ 6. Macro environment } & F61 & Lending interest rates of state banks \\
\hline & F62 & Inflation \\
\hline & F63 & Tax policies \\
\hline & F64 & Political instability \\
\hline & F65 & Technological advances \\
\hline & F66 & Global financial crisis \\
\hline
\end{tabular}




\section{Results and Discussions}

The results of the descriptive statistics analysis of surveyed enterprises are given in Table 2 as follows.

Table 2

Profile of the companies

\begin{tabular}{clcc}
\hline Characteristics & & No. $=102$ & Percent (\%) \\
\hline \multirow{3}{*}{ Revenue } & $<200$ billion VND & 43 & 42.2 \\
& $200-1,000$ billion VND & 30 & 29.4 \\
& $>1.000$ billion VND & 29 & 28.4 \\
\hline \multirow{3}{*}{ Number of employees } & $<200$ people & 71 & 69.6 \\
& $200-1000$ people & 20 & 19.6 \\
& $>1000$ people & 11 & 10.8 \\
\hline \multirow{3}{*}{ Years in construction field } & $<10$ years & 30 & 29.4 \\
& $10-20$ years & 60 & 58.8 \\
& $>20$ years & 12 & 11.8 \\
\hline \multirow{2}{*}{ Listing status } & Unlisted & 36 & 35.3 \\
& Listed & 64 & 64.7 \\
\hline
\end{tabular}

Profile of companies are shown in Table 2. In terms of revenue, out of 102 surveyed enterprises, 43 enterprises with the previous year's revenue reached 200 billion VND at the highest rate, $42.2 \%$. The businesses achieved revenue from 200 to 1,000 billion VND and over 1,000 billion VND are equivalent. In terms of the number of employees, enterprises with under 200 people account for $69.6 \%$, followed by enterprises with 200 to 1,000 people (at the rate of 19.6\%), the rest are enterprises with more than 1,000 people. Thus, according to the classification criteria of the Vietnamese Government, enterprises satisfy the conditions of small and medium enterprises are $42 \%$. In terms of years in the construction sector, the majority of businesses have a number of years from 10 to 20 years $(58.8 \%)$, followed by enterprises with less than 10 years $(29.4 \%)$, the rest are enterprises of over 20 years. According to the listing status, listed companies account for a high proportion $(64.7 \%)$ prepared to unlisted companies.

\section{Table 3}

One-Sample Statistics

\begin{tabular}{|c|c|c|c|c|c|c|}
\hline & Cod & Variables & $\mathrm{N}$ & Mean & Std. Deviation & Std. Error Mean \\
\hline 1 & F31 & Payment duration & 102 & 4.15 & .894 & .089 \\
\hline 2 & F32 & Terms of payment & 102 & 3.98 & .901 & .089 \\
\hline 3 & F33 & Advance payment & 102 & 3.99 & .838 & .083 \\
\hline 4 & F21 & Retained rate & 102 & 3.52 & .841 & .083 \\
\hline 5 & F22 & Time of releasing retention & 102 & 3.38 & .833 & .082 \\
\hline 6 & F23 & Limit of retention & 102 & 3.09 & .822 & .081 \\
\hline 7 & F15 & Loan payment & 102 & 4.01 & .764 & .076 \\
\hline 8 & F16 & Withholding tax & 102 & 3.58 & .826 & 082 \\
\hline 9 & F11 & Payment for suppliers & 102 & 3.81 & .962 & .095 \\
\hline 10 & F12 & Delayed payment for suppliers & 102 & 3.46 & .886 & .088 \\
\hline 11 & F52 & Over work measurement & 102 & 3.18 & .813 & .081 \\
\hline 12 & F51 & Under work measurement & 102 & 3.14 & .912 & .090 \\
\hline 13 & F41 & Cost of materials & 102 & 3.7 & .818 & .081 \\
\hline 14 & F42 & Wages of labor and staff & 102 & 3.99 & .751 & .074 \\
\hline 15 & F43 & Plan and equipment costs & 102 & 3.5 & .793 & .079 \\
\hline 16 & F17 & Bank Interest rate & 102 & 3.52 & 1.041 & .103 \\
\hline 17 & F13 & Selling price adjustment & 102 & 3.39 & .760 & .075 \\
\hline 18 & F53 & Work execution errors & 102 & 3.22 & .863 & .085 \\
\hline 19 & F14 & Claims & 102 & 3.01 & .939 & .093 \\
\hline 20 & F66 & Global financial crisis & 102 & 3.6 & .859 & .085 \\
\hline 21 & F61 & Lending interest rates of state & 102 & 3.72 & .905 & .090 \\
\hline 22 & F62 & Inflation & 102 & 3.63 & .807 & .080 \\
\hline 23 & F63 & Tax policies & 102 & 3.73 & .810 & .080 \\
\hline 24 & F64 & Political instability & 102 & 3.25 & .864 & .086 \\
\hline 25 & F65 & Technological advances & 102 & 3.55 & .779 & .077 \\
\hline
\end{tabular}

The factors in the model are considered to have a positive relationship with cash flow management in construction enterprises. We have used factor analysis method (EFA) to assess the convergence level of 
factors affecting the management of cash flow in construction enterprises. The results show that, with a sample size of 102, sample scale and observed variables are 102: 23, this ratio is greater than 3: 1 and KMO coefficient $=0.624>0.5$ (Table 5 ), the study has enough observable variables to constitute a factor. Sig. $=0<0.05$ indicates that the Bartlett test is statistically significant and the observed variables are correlated. Thus, data are considered suitable for conducting factor analysis. Table 3 and Table 4 present the results of one-sample t-test with the aim of comparing the average score of variables. The test means the value was 3.0 with a $95 \%$ confidence level and the respective critical value $(\mathrm{t})$ were generated using SPSS 22. In Table 3, the average of all scales is greater than 3.0. The hypothesis $\mathrm{H}_{0}$ is that variables with an average value of 3.0 are rejected while the hypothesis $\mathrm{H}_{1}$ states that variables with a mean of 3.0 are acceptable. Observation from the mean value in Table 3 shows that most of the variables reached the mean at the consent level (the mean ranged from 3.41 to 4.2). However, 8 variables have lower average values (mean between 3.01 and 3.38), which are F22, F23, F51, F52, F53, F13, F14, F64. From Table 4, with the level of freedom of choice of 101 observations, the level of test significance of 3 variables $>0.05$ $(\mathrm{F} 23, \mathrm{~F} 51, \mathrm{~F} 14)$ should not reject the hypothesis $\mathrm{H}_{0}(\mathrm{mean}=3)$. Based on the results in Table 3, the mean of these variables has the lowest value (from 3.01 to 3.14), meaning that the comments on these variables can reach the average level. The remaining variables are worth Sig. ( 2 -tailed $)<0.05$ so the hypothesis $\mathrm{H}_{1}$ is approved (all variables have a mean level greater than 3, all scales are at the average level and agree).

\section{Table 4}

One-Sample Test

\begin{tabular}{|c|c|c|c|c|c|c|c|c|}
\hline & \multirow{3}{*}{ Cod } & \multirow{3}{*}{ Variables } & \multicolumn{6}{|c|}{ Test Value $=3$} \\
\hline & & & \multirow{2}{*}{$\mathrm{t}$} & \multirow{2}{*}{$\mathrm{df}$} & \multirow{2}{*}{$\begin{array}{c}\text { Sig. } \\
\text { (2-tailed) }\end{array}$} & \multirow{2}{*}{$\begin{array}{c}\text { Mean } \\
\text { Difference }\end{array}$} & \multicolumn{2}{|c|}{$95 \%$ Confidence Interval of the Difference } \\
\hline & & & & & & & Lower & Upper \\
\hline 1 & F31 & Payment duration & 12.953 & 101 & .000 & 1.147 & .97 & 1.32 \\
\hline 2 & F32 & Terms of payment & 10.992 & 101 & .000 & .980 & .80 & 1.16 \\
\hline 3 & F33 & Advance payment & 11.928 & 101 & .000 & .990 & .83 & 1.15 \\
\hline 4 & F21 & Retained rate & 6.239 & 101 & .000 & .520 & .35 & .68 \\
\hline 5 & F22 & Time of releasing retention & 4.636 & 101 & .000 & .382 & .22 & .55 \\
\hline 6 & F23 & Limit of retention & 1.084 & 101 & .281 & .088 & -.07 & .25 \\
\hline 7 & F15 & Loan payment & 13.345 & 101 & .000 & 1.010 & .86 & 1.16 \\
\hline 8 & F16 & Withholding tax & 7.074 & 101 & .000 & .578 & .42 & .74 \\
\hline 9 & F11 & Payment for suppliers & 8.543 & 101 & .000 & .814 & .62 & 1.00 \\
\hline 10 & F12 & Delayed payment for suppli- & 5.251 & 101 & .000 & .461 & .29 & .63 \\
\hline 11 & F52 & Over work measurement & 2.191 & 101 & .031 & .176 & .02 & .34 \\
\hline 12 & F51 & Under work measurement & 1.519 & 101 & .132 & .137 & -.04 & .32 \\
\hline 13 & F41 & Cost of materials & 8.594 & 101 & .000 & .696 & .54 & .86 \\
\hline 14 & & Wages of labor and staff & 13.313 & 101 & .000 & .990 & .84 & 1.14 \\
\hline 15 & F43 & Plan and equipment costs & 6.369 & 101 & .000 & .500 & .34 & .66 \\
\hline 16 & F17 & Bank Interest rate & 5.041 & 101 & .000 & .520 & .32 & .72 \\
\hline 17 & F13 & Selling price adjustment & 5.212 & 101 & .000 & .392 & .24 & .54 \\
\hline 18 & F34 & Work execution errors & 2.524 & 101 & .013 & .216 & .05 & .39 \\
\hline 19 & F14 & Claims & .105 & 101 & .916 & .010 & -.17 & .19 \\
\hline 20 & F66 & Global financial crisis & 7.032 & 101 & .000 & .598 & .43 & .77 \\
\hline 21 & F61 & Lending interest rates of state & 7.985 & 101 & .000 & .716 & .54 & .89 \\
\hline 22 & F62 & Inflation & 7.848 & 101 & .000 & .627 & .47 & .79 \\
\hline 23 & F63 & Tax policies & 9.043 & 101 & .000 & .725 & .57 & .88 \\
\hline 24 & F64 & Political instability & 2.980 & 101 & .004 & .255 & .09 & .42 \\
\hline 25 & F65 & Technological advances & 7.120 & 101 & .000 & .549 & .40 & .70 \\
\hline
\end{tabular}

Table 5

KMO and Bartlett's Test

Kaiser-Meyer-Olkin Measure of Sampling Adequacy.

Bartlett's Test of Sphericity 
Table 5 shows that the coefficient $\mathrm{KMO}=0.624>0.5$ and $\mathrm{Sig}=0<0.05$ indicates that the variables have a linear relationship with each other and factor analysis is consistent with survey data.

Table 6

Total Variance Explained

\begin{tabular}{|c|c|c|c|c|c|c|c|c|}
\hline \multicolumn{3}{|c|}{ Initial Eigenvalues } & \multicolumn{3}{|c|}{ Extraction Sums of Squared Loadings } & \multicolumn{3}{|c|}{ Rotation Sums of Squared Loadings } \\
\hline Total & $\begin{array}{l}\% \text { of Vari- } \\
\text { ance }\end{array}$ & Cumulative \% & Total & $\begin{array}{c}\% \text { of Vari- } \\
\text { ance }\end{array}$ & Cumulative \% & Total & $\begin{array}{l}\% \text { of Vari- } \\
\text { ance }\end{array}$ & Cumulative $\%$ \\
\hline 7.915 & 35.978 & 35.978 & 7.915 & 35.978 & 35.978 & 3.461 & 15.730 & 15.730 \\
\hline 2.439 & 11.088 & 47.066 & 2.439 & 11.088 & 47.066 & 3.396 & 15.437 & 31.167 \\
\hline 2.265 & 10.295 & 57.360 & 2.265 & 10.295 & 57.360 & 3.372 & 15.328 & 46.495 \\
\hline 1.723 & 7.832 & 65.192 & 1.723 & 7.832 & 65.192 & 2.645 & 12.024 & 58.519 \\
\hline 1.470 & 6.683 & 71.875 & 1.470 & 6.683 & 71.875 & 2.415 & 10.979 & 69.499 \\
\hline 1.245 & 5.661 & 77.536 & 1.245 & 5.661 & 77.536 & 1.768 & 8.037 & 77.536 \\
\hline .797 & 3.622 & 81.158 & & & & & & \\
\hline .716 & 3.253 & 84.411 & & & & & & \\
\hline .558 & 2.537 & 86.948 & & & & & & \\
\hline .512 & 2.325 & 89.273 & & & & & & \\
\hline .427 & 1.941 & 91.214 & & & & & & \\
\hline .419 & 1.905 & 93.119 & & & & & & \\
\hline .296 & 1.346 & 94.465 & & & & & & \\
\hline .260 & 1.181 & 95.646 & & & & & & \\
\hline .236 & 1.074 & 96.720 & & & & & & \\
\hline .172 & .780 & 97.500 & & & & & & \\
\hline .157 & .714 & 98.214 & & & & & & \\
\hline .127 & .578 & 98.793 & & & & & & \\
\hline .097 & .439 & 99.232 & & & & & & \\
\hline .093 & .422 & 99.654 & & & & & & \\
\hline .054 & .247 & 99.902 & & & & & & \\
\hline .022 & .098 & 100.000 & & & & & & \\
\hline
\end{tabular}

As can be seen from Table 6, there are 6 groups of factors with Initial Eigenvalues $>1$ affecting the cash flow management of Vietnamese listed construction enterprises. The total variance extracted is $77,536 \%$, showing that the factors can explain $77,536 \%$ for the influence on the management of cash flow of listed construction companies.

Table 7

Rotated Component Matrix ${ }^{\mathrm{a}}$

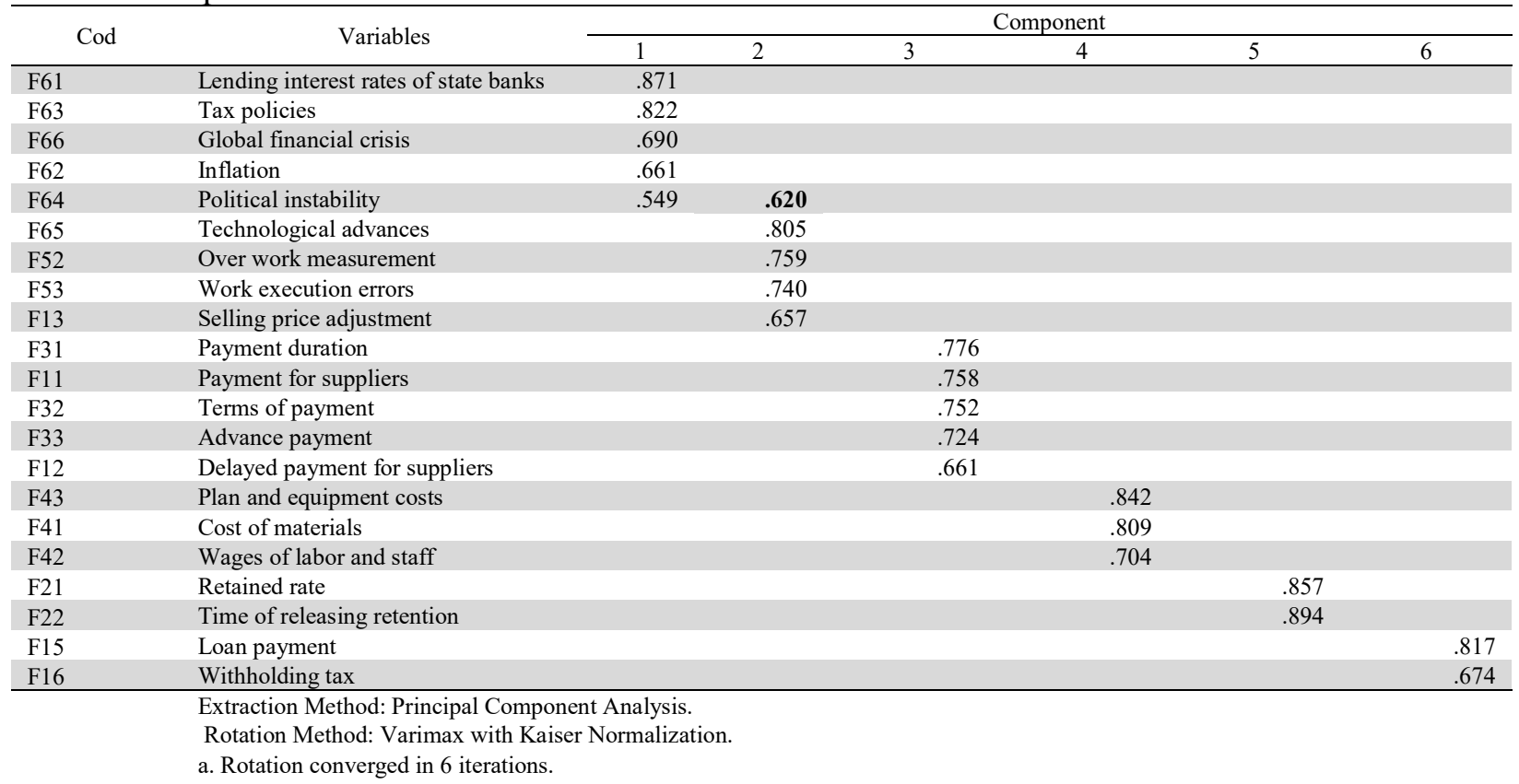


Table 7 shows that 6 groups of factors are formed with the change of scale compared with the original plan. Specifically:

Group 1: Consisting of 4 observed variables: F61, F63, F66, F62, to keep the same group of Macro environment as originally expected.

Group 2: Includes 5 observed variables: 2 variables from Macro environment group (F64, F65), turn F13 from "Financial risk" group and 2 initial variables of "During construction" group (F52, F53). Therefore, these variables are grouped "During construction".

Group 3: Consisting of 5 variables, grouped by 3 variables F31, F32, F33 of "Receivables" group and 2 variables of "Financial risk" group F11, F12. This group is renamed "Payables and Receivables".

Group 4: The "Construction cost" group consists of 3 unchanged variables.

Group 5: The "Retention" group has 2 original variables. Limit of retention is eliminated due to low factor loading factor (less than 0.5).

Group 6: Includes two variables of the group "Financial risk" is "Payment" and "Withholding tax". The new group is named "Payment of principal and tax".

\section{Table 8}

Component Score Coefficient Matrix

\begin{tabular}{|c|c|c|c|c|c|c|c|}
\hline \multirow{2}{*}{ Cod } & \multirow{2}{*}{ Variables } & \multicolumn{6}{|c|}{ Component } \\
\hline & & 1 & 2 & 3 & 4 & 5 & 6 \\
\hline F61 & Lending interest rates of state banks & .337 & -.096 & -.130 & -.075 & .032 & .190 \\
\hline F63 & Tax policies & .287 & .015 & -.087 & -.062 & -.020 & .026 \\
\hline F62 & Inflation & .214 & -.035 & -.048 & .084 & -.032 & -.045 \\
\hline F66 & Global financial crisis & .202 & .036 & .075 & -.042 & .036 & -.328 \\
\hline F65 & Technological advances & .022 & .337 & -.050 & -.146 & -.054 & -.106 \\
\hline F52 & Over work measurement & -.112 & .250 & .010 & .037 & .000 & .004 \\
\hline F53 & Work execution errors & -.023 & .246 & -.076 & -.039 & .049 & .076 \\
\hline F13 & Selling price adjustment & -.013 & .198 & .015 & -.018 & .111 & -.090 \\
\hline F64 & Political instability & .123 & .170 & .007 & -.050 & -.126 & .021 \\
\hline F31 & Payment duration & .013 & -.121 & .316 & -.068 & -.128 & .069 \\
\hline F32 & Terms of payment & -.142 & .036 & .299 & -.058 & .054 & -.081 \\
\hline F11 & Payment for suppliers & -.080 & .080 & .271 & -.037 & -.088 & .005 \\
\hline F33 & Advance payment & -.031 & -.004 & .271 & -.121 & .198 & -.223 \\
\hline F12 & Delayed payment for suppliers & -.023 & -.036 & .209 & .109 & -.187 & .103 \\
\hline F43 & Plan and equipment costs & -.143 & .027 & -.105 & .412 & -.012 & -.001 \\
\hline F41 & Cost of materials & .006 & -.081 & -.016 & .381 & -.012 & -.106 \\
\hline F42 & Wages of labor and staff & .123 & -.134 & -.070 & .338 & -.031 & -.023 \\
\hline F22 & Time of releasing retention & -.027 & .050 & -.117 & -.043 & .446 & -.071 \\
\hline F21 & Retained rate & -.013 & -.045 & -.015 & -.028 & .390 & -.018 \\
\hline F16 & Withholding tax & -.066 & .120 & -.073 & -.018 & -.015 & .399 \\
\hline F15 & Loan payment & .027 & -.059 & .027 & -.100 & -.050 & .518 \\
\hline
\end{tabular}

Extraction Method: Principal Component Analysis.

Rotation Method: Varimax with Kaiser Normalization.

Component Scores.

Table 8, variables with the highest factor loading and component score coefficient from the rotated component matrix and component score matrix were selected significantly.

In the group of factor 1, "Macro environment", observed variables F61 "Lending interest rates of state banks" has the strongest impact (0.337) followed by "Tax policies" $(0.287)$. Variable "Global financial crisis" has the weakest impact (0.202).

In the group of factor 2 "During construction" and "Technological advances" have the strongest impacts (0.337). The variable with the least impact is "Political instability" $(0.170)$.

In the group of factor 3 "Payables and Receivables", had quite similar effects, of which, the highest impact is "Payment duration" and the lowest is "Delayed payment for suppliers".

Group of "Construction cost" has variables with high impact levels, "Plan and equipment costs" has the greatest impact, followed by "Cost of materials".

The "Retention" group also has a high weight, "Time of releasing retention" is higher than "Retained rate". 
The group of "Principal loan and tax payment" has the highest weighting factor, "Loan Payment" is higher than "Withholding tax".

\section{Conclusions and recommendations}

The construction companies listed on the stock exchange of Vietnam largely are formed through the process of equitization of state-owned enterprises, so the management in general, as well as the effective control and use of cash flow, are not flexible and responsive to the decision of the administrator. It is necessary to identify the factors affecting cash flow management for construction companies listed on the Vietnam stock exchange. Research results have pointed out 6 groups of factors affecting the cash flow of listed construction companies on Vietnam's stock exchange, namely: Macro environment; During construction; Payables and Receivables; Construction cost; Retention; Loan payment and tax. In addition, the research has also determined the weight of each variable in each factor to the cash flow of construction companies listed on the Vietnam stock exchange. The determination of 6 groups of factors influencing cash flow management will be a useful information channel for managers of construction companies listed on the Vietnamese stock exchange in making decisions. In addition, the weighting effects of each element in the factor will be suggestions for administrators in choosing the priority for each of these factors. This result can also be applied more widely for Vietnamese construction enterprises.

\section{References}

Arditi, D., \& Chotibhongs, R. (2005). Issues in subcontracting practice. Journal of Construction Engineering and Management, 131(8), 866-876.

Bausman, D. C. (2004). Retain age practice in the construction industry, foundation of the American subcontractors' association. Contractors' Knowledge Quest Research Series, 1-28.

Bento, A., \& Bento, R. (2006). Factors affecting the outcomes of performance management systems. AMCIS 2006 Proceedings, 7.

Buertey, J. I., \& Adjei-Kumi, T. (2012). Cash flow forecasting in the construction industry: The case of Ghana, Pentvars. Business Journal, , 65-81.

Dosumu, B. (2015). Material management on construction sites (a case study of cement management in ibadan, oyo state). Retrieved from https://www.researchgate.net/publica

El-Kholy, A. M. (2014). A Multi-Objective Fuzzy Linear Programming Model for Cashflow Management. International Journal of Engineering Research and Applications (IJERA), 4(8), 152-163.

Garner, J. (2012). Cash flow Forecasting: RICS Guidance Note, 1st Edition (GN 79/2011). Royal Institution of Chartered Surveyors (RICS).

Gundecha, M. M. (2018, 7 15). Study of factors affecting labor productivity at building construction project in the USA: Web Survey, Unpublished. Retrieved from http://library.ndsu.edu/tools/dspace/load/?file=/repository/bitstream/handle/10365/22772/Gundech a_Mahesh.pdf?sequen

Issa, A., \& Zayed. (2007). Cash flow analysis of construction projects. Retrieved from https://www.researchgate.net/figure/Comparing-the-newly-developed-model-with-Al-Issa-and-Zayed-2007-maincategories_fig1_266289526

Ivan, K. (2017). Cash Flow Management. Case: RE Trading LLC. Thesis of Saimaa University of Applied Sciences.

Jack, O. A. (2018). Environmental Factors Affecting Business. Retrieved from https://www.academia.edu/15768537/Environmental_Factors_Affecting_Business

Jiang, A., Issa, R. R., \& Malek, M. (2011). Construction project cash flow planning using the Pareto optimality efficiency network model. Journal of Civil Engineering and Management, 17(4), 510-519.

Ling, F. Y. Y., \& Liu, M. (2005). Factors considered by successful and profitable contractors in markup size decision in Singapore. Building and environment, 40(11), 1557-1565.

Park, H. K., Han, S. H., \& Russell, J. S. (2005). Cash flow forecasting model for general contractors using moving weights of cost categories. Journal of Management in Engineering, 21(4), 164-172. 
Prime Minister. (2018, 7 6). Decision on the management of vietnam's economic sector system, No. 27/2018/QD-TTg.

Ramachandra, T., \& Rotimi, J. O. B. (2015). Causes of payment problems in the New Zealand construction industry. Construction Economics and Building, 15(1), 43-55.

Tarek, Z., \& Yaqiong, L. (2014). Cash flow modeling for construction projects, ISSN: 0969-9988.

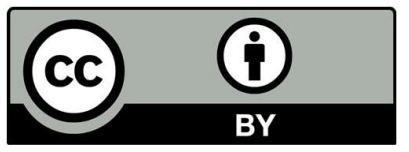

(C) 2019 by the authors; licensee Growing Science, Canada. This is an open access article distributed under the terms and conditions of the Creative Commons Attribution (CCBY) license (http://creativecommons.org/licenses/by/4.0/). 